\title{
Treating MS after surviving PML: Discrete strategies for rescue, remission, and recovery patient 2
}

From the National Multiple Sclerosis Society Case Conference Proceedings

Neurol Neuroimmunol Neuroinflamm 2021;8:e968. doi:10.1212/NXI.0000000000000968

In the Neurolog $y^{\circledR}$ Neuroimmunology \& Neuroinflammation Article "Treating MS after surviving PML: Discrete strategies for rescue, remission, and recovery patient 2: From the National Multiple Sclerosis Society Case Conference Proceedings" by R. Cruz et al., the 15 th author's name and credentials should be listed as "Scott D. Newsome, DO." The authors regret the error.

\section{Reference}

1. Cruz R, Hogan N, Sconzert J, et al. Treating MS after surviving PML: Discrete strategies for rescue, remission, and recovery patient 2: from the National Multiple Sclerosis Society Case Conference Proceedings. Neurol Neuroimmunol Neuroinflamm 2021;8:e930. doi: 10.1212/NXI.0000000000000930. 


\section{Neurology \\ Neuroimmunology \& Neuroinflammation}

Treating MS after surviving PML: Discrete strategies for rescue, remission, and recovery patient 2: From the National Multiple Sclerosis Society Case Conference Proceedings

Neurol Neuroimmunol Neuroinflamm 2021;8;

DOI 10.1212/NXI.0000000000000968

This information is current as of February 1, 2021

Updated Information \&

Services

References

Permissions \& Licensing

Reprints including high resolution figures, can be found at:

http://nn.neurology.org/content/8/2/e968.full.html

This article cites 1 articles, 0 of which you can access for free at: http://nn.neurology.org/content/8/2/e968.full.html\#\#ref-list-1

Information about reproducing this article in parts (figures,tables) or in its entirety can be found online at:

http://nn.neurology.org/misc/about.xhtml\#permissions

Information about ordering reprints can be found online:

http://nn.neurology.org/misc/addir.xhtml\#reprintsus

Neurol Neuroimmunol Neuroinflamm is an official journal of the American Academy of Neurology.

Published since April 2014, it is an open-access, online-only, continuous publication journal. Copyright $\odot$ 2021 American Academy of Neurology. All rights reserved. Online ISSN: 2332-7812.

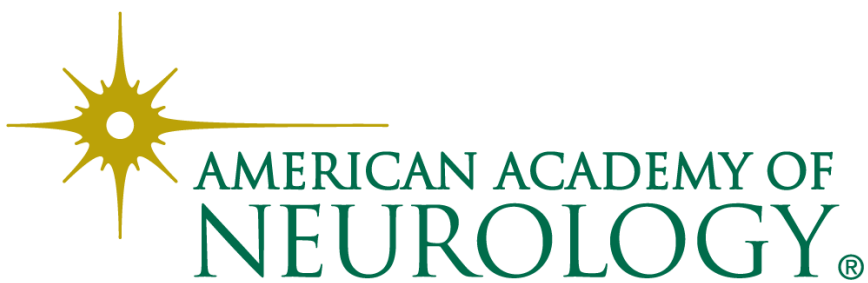

